\title{
Development of a versatile tool for the simultaneous differential detection of Pseudomonas savastanoi pathovars by End Point and Real-Time PCR
}

\author{
Stefania Tegli*`, Matteo Cerboneschi ${ }^{\dagger}$, Ilaria Marsili Libelli and Elena Santilli
}

\begin{abstract}
Background: Pseudomonas savastanoi pv. savastanoi is the causal agent of olive knot disease. The strains isolated from oleander and ash belong to the pathovars nerii and fraxini, respectively. When artificially inoculated, pv. savastanoi causes disease also on ash, and pv. nerii attacks also olive and ash. Surprisingly nothing is known yet about their distribution in nature on these hosts and if spontaneous cross-infections occur. On the other hand sanitary certification programs for olive plants, also including P. savastanoi, were launched in many countries. The aim of this work was to develop several PCR-based tools for the rapid, simultaneous, differential and quantitative detection of these $P$. savastanoi pathovars, in multiplex and in planta.

Results: Specific PCR primers and probes for the pathovars savastanoi, nerii and fraxini of P. savastanoi were designed to be used in End Point and Real-Time PCR, both with SYBR ${ }^{\circ}$ Green or TaqMan ${ }^{\circ}$ chemistries. The specificity of all these assays was $100 \%$, as assessed by testing forty-four P. savastanoi strains, belonging to the three pathovars and having different geographical origins. For comparison strains from the pathovars phaseolicola and glycinea of P. savastanoi and bacterial epiphytes from P. savastanoi host plants were also assayed, and all of them tested always negative. The analytical detection limits were about $5-0.5 \mathrm{pg}$ of pure genomic DNA and about $10^{2}$ genome equivalents per reaction. Similar analytical thresholds were achieved in Multiplex Real-Time PCR experiments, even on artificially inoculated olive plants.

Conclusions: Here for the first time a complex of PCR-based assays were developed for the simultaneous discrimination and detection of P. savastanoi pv. savastanoi, pv. nerii and pv. fraxini. These tests were shown to be highly reliable, pathovar-specific, sensitive, rapid and able to quantify these pathogens, both in multiplex reactions and in vivo. Compared with the other methods already available for P. savastanoi, the identification procedures here reported provide a versatile tool both for epidemiological and ecological studies on these pathovars, and for diagnostic procedures monitoring the asymptomatic presence of $P$. savastanoi on olive and oleander propagation materials.
\end{abstract}

\section{Background}

Olive knot disease is a plant disease characterized by hyperplastic symptoms mainly on twigs, young branches and the trunk, more rarely on leaves and fruits, of olive trees (Olea europaea L.), which exists worldwide wher-

* Correspondence: stefania.tegli@unifi.it

1 Dipartimento di Biotecnologie Agrarie, Sez. Patologia vegetale, Laboratorio di Patologia Vegetale Molecolare, Università degli Studi di Firenze, Via della

Lastruccia 10, 50019 Sesto Fiorentino, Firenze, Italy

+ Contributed equally

Full list of author information is available at the end of the article ever this crop is cultivated. This disease is particularly damaging as far as quantitative and qualitative production is concerned [1,2], and causes heavy losses in the countries of the Mediterranean basin where olive plants are extensively cultivated. The causal agent is the plant pathogenic bacterium Pseudomonas savastanoi pv. savastanoi (Psv) [3,4], isolated and described for the first time by Luigi Savastano [5,6]. Psv enters and infects plants generally through wounds of different origin (i.e. pruning and mechanical wounds, frost injuries, leaf scars) [7]. The 
pathological process depends on the expression of bacterial hrp genes [8], and the development of the spherical knots is caused by phytohormones (3-indoleacetic acid and cytokinins) synthesized by Psv, that trigger uncontrolled proliferation of the cells surrounding the site of infection [9-13]. In the species P. savastanoi were also included isolates from oleander (Nerium oleander L.), ash (Fraxinus excelsior L.) and other plants, such as privet (Ligustrum japonicum Thunb.), Jasminum spp. and Retama sphaerocarpa (Boiss.) L., and the taxonomy and the classification of this bacterium have been controversial for a long time. The strains isolated from olive, oleander and ash can be differentiated according to a series of characteristics concerning host range, production of phytohormones and bacteriocins, assimilation of different carbon sources, monoclonal antibodies, analysis of whole cell fatty acids, DNA relatedness, low molecular weight restriction fragments, restriction fragment length polymorphism (RFLP) and fluorescent amplified fragment length polymorphism (f-AFLP) [3,12,14-24]. Moreover the genetic diversity of strains isolated from olive trees was recently deeply investigated [25-28]. According to all these data, the name Psv is now used to indicate isolates from olive, while the names P. savastanoi pv. nerii (Psn) and $P$. savastanoi pv. fraxini (Psf) are accepted for those strains isolated from oleander and ash, respectively [4].

The strategies to control olive knot mainly aim to reduce the spread of the disease, with general cultural practices such as pruning, particularly of affected branches, and the conventional use of copper compounds. Up to now no commercial olive cultivars resistant to Psv are available yet, but some researches on this topic have been reported [29-32]. Sources of inoculum for new infections are represented by Psv populations surviving within the young knots, but also by Psv naturally resident on healthy olive trees as epiphyte on the phylloplane, on the surfaces of stems and olive fruits. Psv epiphytic populations are important sources of inoculum for new infections, and their density is related to the season and the age of leaves, with the greatest damages observed when weather conditions were conducive both for the growth of Psv as epiphyte and its entry into the olive bark [33-38]. Thus, also considering the increasing spread of resistance to copper compounds among $P$. syringae pathovars and related bacteria [39,40], sensitive and specific methods to monitor Psv natural epiphytic population on olive trees are needed to contribute to the successful preventive control and management of this disease. Moreover, Psv is among the infective agents of olive, whose absence has to be ascertained for the production of certified olive plants [41].

Traditional microbiological methods for the detection and identification of Psv are available [42,43], but they have low sensitivity and specificity, and they are quite time consuming. For this reason some protocols were developed for the detection of Psv, by conventional, enriched and nested PCR, working also in planta and in asymptomatic tissues [44-46]. These assays showed high levels of sensitivity, but they were unsuitable to accurately and reliably quantify the target phytopathogen. Moreover all these assays, as well as a sensitive and quantitative Real-Time PCR procedure developed for Psn detection in oleander plants [47], used primers designed on the sequence of iaaL gene, which encodes the conversion of IAA to IAA-lysine. But being this target common to all the isolates of Psv, Psn and Psf, none of these methods results to be pathovar-specific, while it is known that under experimental conditions Psn strains are able to infect olive [24], and that Psf strains are able to multiply in olive bark when artificially inoculated, although to a lower level than strains isolated from olive or oleander [21]. Since nothing is known yet about their distribution in nature on the different host plants and whether spontaneous cross-infections occur, pathovar-specific molecular protocols for the discrimination of Psv, Psn and Psf would be urgently needed, firstly to clarify this aspect of their epidemiology and then to avoid false positive results derived from the application of the above mentioned detection methods in sanitary certification programmes.

In this paper we describe the development of reliable PCR-procedures for the specific discrimination and quantification of Psv, Psn and Psf, both in vitro and in planta as epiphytes, by End Point PCR and Real-Time PCR, using two different technologies, the SYBR ${ }^{\circ}$ Green I detection dye and three pathovar-specific TaqMan hybridisation probes. Primers and probes specific for $P s v$, $P s n$ and Psf were designed upon the sequence data of cloned fragments, previously amplified in Repetitivesequence-based PCR (Rep-PCR) experiments with strains belonging to the three pathovars of $P$. savastanoi examined in this study using Enterobacterial Repetitive Intragenic Consensus (ERIC) primers [48]. These procedures have high sensitivity, specificity, rapidity and represent valid and innovative diagnostic tools that can suit all phytopathological laboratories, according to their equipment and skills, in order to promote and encourage the use of molecular detection methods for Psv in the frame of the certification programs for olive propagation materials.

\section{Results}

Identification of $P$. savastanoi pathovar-specific sequences by ERIC-PCR and design of pathovar-specific primers

The identities of $P$. savastanoi strains shown in Table 1 were confirmed by $16 \mathrm{~S}$ rDNA sequencing and pathogenicity trials (data not shown). On these strains, Rep-PCR experiments with ERIC1R and ERIC2 primers were performed and the results referring to some representative 
strains for each $P$. savastanoi pathovar examined are shown in Figure 1. The genomic ERIC-PCR profiles were highly reproducible; they consisted of bands ranging in size from 400 to 5,000 bp and were pathovar-specific. For each $P$. savastanoi pathovar at least a single and unique band, appearing in all the strains belonging to the same pathovar, was detected. The sizes were approximately 1,600, 830 and 1,350 bp in Psv, Psn and Psf, respectively (Figure 1). These pathovar-specific bands were then separately isolated and purified from agarose gels, cloned and analyzed for their nucleotidic sequences composition. Each band was demonstrated to consist of several fragments of the same size but having different nucleotidic sequences, which were then individually DIG-labeled and used as probes in dot blot hybridization experiments performed under high stringency with the genomic DNAs of Psv, Psn and Psf previously blotted to nylon film (data not shown). The sequences assessed to be pathovar-specific in hybridization experiments were then analyzed using the BLASTN and BLASTX softwares, and further comparisons were made with the CLUSTALW2 program. According to the data so obtained and concerning their specificity, three ERIC-derived clones were selected, one for each pathovar [GenBank:FM253089; GenBank:FM253090; GenBank:FM253091]. Clone FM253090 from Psn did not show any significant homology with any nucleotidic or aminoacidic sequence present in the main databases. Clone FM253089 from Psv had a quite significant homology (82-67\%) near its 3' end with putative transcriptional regulators belonging to the TetR family, while no homology was ever detected with any nucleotidic sequence. On the contrary, clone FM253091 from Psf showed a significant homology both in BLASTX and BLASTN analysis (88-74\% and $99-51 \%$, respectively) with sequences related to proteins belonging to the so called

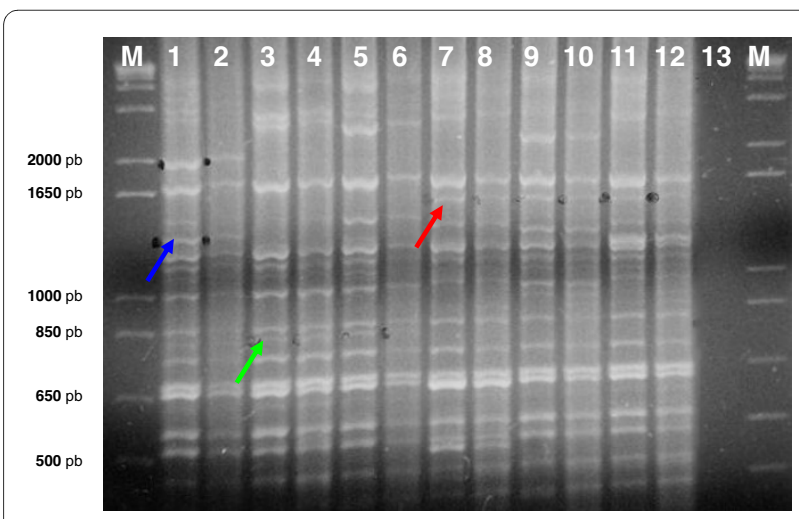

Figure 1 ERIC-PCR fingerprintings of $P$. savastanoi strains belonging to the pathovars Psv, Psn and Psf. Pathovar-specific amplification bands are indicated by red, green and blue arrows for PSV, Psn and Psf, respectively. (See online for a colour version of this figure). M, marker $1 \mathrm{~Kb}$ Plus Ladder (Invitrogen Inc.). lanes 1-2: Psfstrains; lanes 3-6: Psn strains; lanes 7-12: Psv strains; lane 13: DNA-free negative control.
"VirD4/TraG family" of Type Four Secretion System [49]. By hybridization experiments clones FM253089 and FM253090 were demonstrated to be located on bacterial chromosome, while clone FM253091 was located on a plasmid of about $24 \mathrm{~kb}$ (data not shown). These three clones were further analysed in order to identify for each of them conserved regions specifically present in all the strains of the same pathovar, then used to design pathovar-specific primers and probes for End Point and RealTime PCR (Table 2).

\section{End Point PCR assays for Psv, Psn and Psf specific detection}

In order to obtain information about their specificity and sensitivity, the primer pairs $P s v \mathrm{~F} / P s v \mathrm{R}, P s n \mathrm{~F} / P s n \mathrm{R}$ and $P s f \mathrm{~F} / P_{s f \mathrm{R}}$, whose sequences and descriptions are reported in Table 2, were evaluated in End Point PCR assays using as template the genomic DNA of strains Psv ITM317, Psn ITM519 and Psf NCPPB1464, which are representative of their pathovars. For each primer set several serial tenfold dilutions of genomic DNA (from $50 \mathrm{ng}$ to $0.05 \mathrm{pg}$ ) of the isolate belonging to the pathovar for which that primer pair was supposed to be specific were used as template. Genomic DNAs (50 ng/reaction) extracted from each one of the other two $P$. savastano $i$ isolates, from olive, oleander, ash and oak, and from pooled samples of bacterial epiphytes isolated from these plants were also tested. The results obtained are shown in Figure 2, where $1 / 5$ of the reaction volume for each sample tested was loaded onto the agarose gel, to better compare the data. A single amplicon was produced with each primer pair of the three tested, specifically when the DNA template was from the P. savastanoi pathovar for which the primer set was designed. The size of each amplicon was as expected: $388 \mathrm{bp}$ for $P s v \mathrm{~F} / P s v \mathrm{R}, 349 \mathrm{bp}$ for $P s n \mathrm{~F} / P s n \mathrm{R}$ and $412 \mathrm{bp}$ for $P s f \mathrm{~F} / P_{s} f \mathrm{R}$, with DNA template from strains Psv ITM317, Psn ITM519 and Psf NCPPB1464, respectively. No amplicons were ever obtained with no target DNA, either from olive, oleander, ash and oak or from the pools of bacterial epiphytes from P. savastanoi host plants. The sensitivity of these PCR assays was estimated by determining the lowest amount of DNA template detected, that was found to be approximately $5 \mathrm{pg}$ for the primer sets $P s n \mathrm{~F} / P s n \mathrm{R}$ and $P s f \mathrm{~F} / P_{s} f \mathrm{R}$, and $0.5 \mathrm{pg}$ for the pair $P s v \mathrm{~F} / P s v \mathrm{R}$, here corresponding to DNA concentrations of 0.2 and $0.02 \mathrm{pg} / \mu \mathrm{l}$, respectively (Figure 2).

For further testing the pathovar-specificity of the End Point PCR detection methods developed in this study, genomic DNAs from the bacteria listed in Table 1 were also assayed (50 ng/reaction). Forty-four $P$. savastanoi strains, belonging to three $P$. savastanoi pathovars here examined and having different geographic origins, were tested. For comparison, strains 1449B of P. savastanoi pv. phaseolicola (Psp) and PG4180 P. savastanoi pv. glycinea 
Table 1: Bacteria used in this study.

\begin{tabular}{|c|c|c|c|c|c|c|c|c|}
\hline \multirow{3}{*}{$\begin{array}{l}\text { Straina } \\
\text { P.savastanoi pv. savastanoi }\end{array}$} & \multirow{3}{*}{$\begin{array}{l}\text { Host plant of } \\
\text { isolation }\end{array}$} & \multirow{3}{*}{$\begin{array}{l}\text { Geographical } \\
\text { origin }\end{array}$} & \multicolumn{3}{|c|}{ End Point PCR } & \multicolumn{3}{|c|}{ Real-Time PCR } \\
\hline & & & \multicolumn{3}{|c|}{ pathovar- specific primer pairs } & \multicolumn{3}{|c|}{ pathovar- specific primers/probes } \\
\hline & & & Psv & Psn & Psf & Psv-RT & Psn-RT & Psf-RT \\
\hline $\begin{array}{l}\text { ITM317, IPVCT-3, LPVM22, } \\
\text { LPVM510, LPVM602, ES47b, } \\
\text { ES49b, ESB50b, PVBa223 }\end{array}$ & olive & Southern Italy & + & - & - & + & - & - \\
\hline 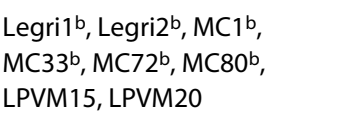 & olive & Central Italy & + & - & - & + & - & - \\
\hline ITMKS1, ITMKL1, ST2 b & olive & Greece & + & - & - & + & - & - \\
\hline $1657-8^{c}$ & olive & Spain & + & - & - & + & - & - \\
\hline DAR7635d & olive & Australia & + & - & - & + & - & - \\
\hline \multicolumn{9}{|l|}{ P. savastanoi pv. nerii } \\
\hline 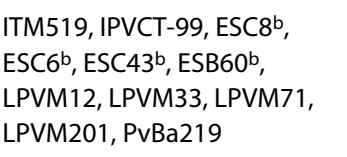 & oleander & Southern Italy & - & + & - & - & + & - \\
\hline ITM601, ES23b, LPVM103 & oleander & Northern Italy & - & + & - & - & + & - \\
\hline NCPPB640 & oleander & Ex-Yugoslavia & - & + & - & - & + & - \\
\hline \multicolumn{9}{|l|}{ P. savastanoi pv. fraxini } \\
\hline NCPPB1006, NCPPB1464 & ash & $\begin{array}{l}\text { United } \\
\text { Kingdom }\end{array}$ & - & - & + & - & - & + \\
\hline PD120 & ash & $\begin{array}{l}\text { The } \\
\text { Netherlands }\end{array}$ & - & - & + & - & - & + \\
\hline CFBP1838, CFBP2093 & ash & France & - & - & + & - & - & + \\
\hline $\mathrm{MCa}^{\mathrm{b}}{ }, \mathrm{MCa}^{\mathrm{b}}$ & ash & Italy & - & - & + & - & - & + \\
\hline $\begin{array}{l}\text { P. savastanoi pv. phaseolicola } \\
1449 \mathrm{~B} \text { e }\end{array}$ & $\begin{array}{l}\text { Lablab } \\
\text { purpureus }\end{array}$ & Ethiopia & - & - & - & - & - & - \\
\hline $\begin{array}{l}\text { P. savastanoi pv. glycinea } \\
\text { PG4180f }\end{array}$ & soybean & New Zealand & - & - & - & - & - & - \\
\hline Unidentified bacteriag & $\begin{array}{l}\text { olive, oleander, } \\
\text { ash }\end{array}$ & Central Italy & - & - & - & - & - & - \\
\hline $\begin{array}{l}\text { a CFBP, Collection Française de } \\
\text { Tecnologie Fitosanitarie, Univ } \\
\text { Parassiti vegetali, C. N. R., Bari, } \\
\text { Biotecnologie Agrarie, Univers } \\
\text { www.ncppp.com/; PD, Culture } \\
\text { Patologia Vegetale, Università } \\
\text { b from E. Santilli and M. Cerbor } \\
\text { c from M. M. Lopez } \\
\text { d from E. J. Cother } \\
\text { e from R. W. Jackson } \\
\text { ffrom M. S. Ullrich }\end{array}$ & $\begin{array}{l}\text { Bactéries Phytop } \\
\text { ersità degli Studi } \\
\text { Italy (from A. Sistc } \\
\text { ità degli Studi di } \\
\text { collection of Plan } \\
\text { degli Studi di Bar } \\
\text { eschi }\end{array}$ & $\begin{array}{l}\text { thogènes, INRA, } \\
\text { Catania, Italy (frc } \\
\text {; LPVM, Culture } \\
\text { renze; NCPPB, Na } \\
\text { Protection Servic } \\
\text { Italy (from A. Sist }\end{array}$ & $\begin{array}{l}\text { Angers, } \\
\mathrm{m} \text { V. Ca } \\
\text { ollectio } \\
\text { tional C } \\
\text { e, Wage } \\
\text { ). }\end{array}$ & $\begin{array}{l}\text { ce; IPV } \\
\text {; ITM, C } \\
\text { Labora } \\
\text { tion of } \\
\text { yen, The }\end{array}$ & $\begin{array}{l}\text { ure colle } \\
\text { collection } \\
\text { Patologi } \\
\text { athogen } \\
\text { rlands; P }\end{array}$ & $\begin{array}{l}\text { tion of } \mathrm{Di} \\
\text { of Istitut } \\
\text { Vegetale } \\
\text { c Bacteria } \\
\text { Ba, Cultu }\end{array}$ & $\begin{array}{l}\text { timento d } \\
\text { ssine e M } \\
\text { olecolare, } \\
\text { rk, UK htt } \\
\text { ollection }\end{array}$ & $\begin{array}{l}\text { ze e } \\
\text { ine da } \\
\text { mento di } \\
\text { rtimento di }\end{array}$ \\
\hline
\end{tabular}


Table 2: Nucleotide sequences of PCR primers and probes used and developed in this study.

\begin{tabular}{|c|c|c|c|c|}
\hline Primer/Probea & Sequence (5'-3') & Positionb & Product size (bp) & Accession Number \\
\hline PsvF & GGCGATGTTCTCAGCGGATTTG & 24 & 388 & $\underline{F M 253081}$ \\
\hline PsvR & GATCAAGTGTCCAAGGAAGTGAAGG & & & FM253082 \\
\hline PsvRT-F & CGGATTTGGTTTGCGGGGTA & 38 & 298 & FM253083 \\
\hline PsvRT-R & AATGGGGTGACACTAAAAATTGTGAA & & & FM253084 \\
\hline PsvRT-P & $($ HEX) CTCGTGCGATCTAAACAGCCGTAGC (BHQ-1)c & 278 & & FM253085 \\
\hline PsnF & АССССТСАTTGTAACGGATG & 1 & 349 & $\underline{A M 051225}$ \\
\hline PsnR & TCCCCGGAATTCAACACTTA & & & $\underline{A M 051226}$ \\
\hline PsnRT-F & GСTCATTCGCTTGTTATCACTTCA & 181 & 169 & AM086621 \\
\hline PsnRT-R & TCCCCGGAATTCAACACTTA & & & $\underline{A M 051226}$ \\
\hline PsnRT-P & $($ FAM ) TACGCCCGACGCCCGAGCCA (BHQ-1)c & 206 & & FM253086 \\
\hline PsfF & CGCCTGCTGTACTCCTCGG & 1 & 412 & AM055834 \\
\hline PsfR & TCGACCTGTCTAAGGCCC & & & AM055835 \\
\hline PsfRT-F & CAGCTCATCCATTAATAGGGCAAG & 207 & 227 & AM086622 \\
\hline PsfRT-R & GGGCAGTGTCAGGGGATG & & & $\underline{F M 253088}$ \\
\hline PsfRT-P & (Texas Red)CTTGTACCGAAGCGTGCCGTCTGC (BHQ-2)c & 237 & & FM253087 \\
\hline
\end{tabular}

a $F$, forward; R, reverse; RT, RealTime; $P$, probe.

b Starting nucleotide position of forward primers and TaqMan ${ }^{\circ}$ probes on target sequences.

c BHQ-1 and BHQ-2 are quencher molecules available from the manufacturer.

$(P s g)$, taxonomically closely related to the pathovars of our interest, were also included in this study. In Table 1 the results obtained are schematically reported: the signs + and - indicate the presence or absence of the expected amplicons, respectively. The pathovar-specificity of each primer pair was confirmed and all the strains belonging to a pathovar were correctly identified when tested with the primer set supposed to be specific for that pathovar. No unspecific amplifications were ever generated, confirming that these End Point PCR assays are highly specific and able to discriminate strains belonging to Psv, Psn and $P s f$.

\section{SYBR ${ }^{\circ}$ Green Real-Time PCR assays for Psv, Psn and Psf specific detection}

On the ERIC pathovar-specific sequences and internal to the annealing sites for the End Point PCR primers, three primer sets to be used in Real-Time PCR were designed, one for each $P$. savastanoi pathovar examined. The specificity of these primer pairs, named PsvRT-F/PsvRT-R, PsnRT-F/PsnRT-R, PsfRT-F/PsfRT-R (Table 2), was preliminarily assessed by BLAST analysis. Then these primer sets were tested in Real-Time PCR runs with SYBR Green as fluorescent marker and $1 \mu \mathrm{l}$ of DNA template extracted from $1 \mathrm{ml}$ of titrated suspensions (corresponding to about $10^{3}$ to $10^{7} \mathrm{CFU} /$ reaction) of strains Psv ITM317, Psn ITM519 and Psf NCPPB1464. Since SYBR Green binds to the minor grooves of a DNA double-chain as it is forming, this fluorescent dye can bind to all amplicons produced in a PCR reaction. Therefore, the specificity of detection can be provided by a pair of primers only when the increase in fluorescence is generated by a single amplicon with a distinct melting temperature (Tm). For this reason dissociation analysis is crucial in SYBR $^{\circ}$ Green PCR experiments. The melting curves obtained with the primer pairs developed in this study are shown in Figure 3.

For all the five different cell concentrations a single melting peak at $85.5^{\circ} \mathrm{C}( \pm 0.1)$ was observed with the primer pair $P s v \mathrm{RT}-\mathrm{F} / P s v \mathrm{RT}-\mathrm{R}$ and DNA extracted from isolate Psv ITM317, to indicate that the total fluorescent signal was contributed by specific amplicons. No signals were recorded in melting point analysis with the set PsvRT-F/PsvRT-R in DNA-free control and when no target DNAs were used as template (Figure 3). The pair PsnRT-F/PsnRT-R obtained a similar specificity, giving a unique melting peak at $85.0^{\circ} \mathrm{C}( \pm 0.1)$ only with DNA from strain Psn ITM519, as well as the primer set PsfRTF/PsfRT-R that originated a single peak at $86.5^{\circ} \mathrm{C}( \pm 0.1)$ only with DNA from strain Psf NCPPB1464. In these 


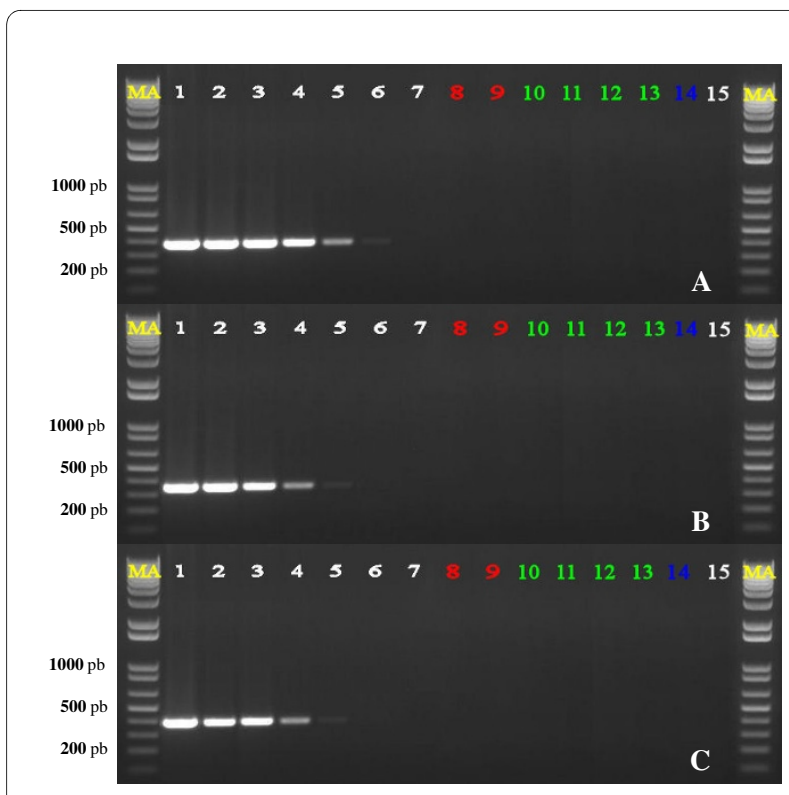

Figure 2 Specificity and detection limit of End Point PCR assays.(A) primer set PsVF/PsVR on strain PsV ITM317; (B) primer set PsnF/ PsnR on strain Psn ITM519; (C) primer set PsfF/PsfR on strain Psf NCPPB1464. M, marker 1 Kb Plus Ladder (Invitrogen Inc.). lanes 1-7: genomic DNA from the target $P$. savastanoi pathovar (serial tenfold dilutions, from 50 ng to $0.05 \mathrm{pg}$ per reaction); lanes 8-9: genomic DNA from the non-target P. savastanoi pathovars (50 ng/reaction); lanes 10-13: plant genomic DNA (50 ng/reaction), from olive, oleander, ash and oak, respectively; lane 14: genomic DNA (50 ng/reaction) from a pool of bacterial epiphytes isolated in this study from olive (A), oleander (B) and ash leaves (C); lane 15, DNA-free negative control;

cases as well, DNA-free controls and the DNAs supposed not to be specific for these primers tested negative (Figure 3), unless spiked with target DNA specific for the primer pair used (data not shown). The pathovar-specificity of each primer pair was further confirmed using as template DNAs from the bacteria listed in Table 1. The results obtained are schematically reported for each strain; the signs + and - indicate the presence or absence of the expected melting peak, respectively (Table 1). Moreover the amplicons produced by SYBR ${ }^{\circ}$ Green RealTime PCR were visualized by gel electrophoresis. Single bands of the expected sizes of 298, 169 and 227 bp were specifically generated with the primer sets PsvRT-F/ PsvRT-R, PsnRT-F/PsnRT-R, PsfRT-F/PsfRT-R and isolates belonging to Psv, Psn and Psf, respectively, and no aspecific amplification products were ever observed (data not shown).

In Figure 3 the sensitivity of each pathovar-specific primer pair is also represented. For each primer set increasing amounts of the specific target DNA corresponded to higher melting peaks having the same Tm, and DNA as small as that extracted from $10^{3} \mathrm{CFU}$ could be easily detected.
The standard curves for the absolute quantification of the DNA target by SYBR ${ }^{\circ}$ Green Real-Time PCR detection methods here developed were generated by evaluating the $\mathrm{Ct}$ values versus the log of DNA concentration of each tenfold dilution series (from $50 \mathrm{ng}$ to $5 \mathrm{fg}$ per reaction). As shown in Figure 3 the linearity of the quantification was demonstrated over a range of five logs (from 50 ng to $5 \mathrm{pg} /$ reaction), with excellent correlation coefficients $\left(\mathrm{R}^{2}\right)$ of $0.999,0.998$ and 0.998 for pathovar-specific primer sets PsvRT, PsnRT and PsfRT, respectively. The slopes of the standard curves (between -3.488 and -3.711) were equivalent to PCR efficiencies ranging from 93.5 to $86.0 \%$, to indicate that these SYBR Green Real-Time PCR assays are solid even with low DNA target concentrations, as further confirmed when the $\mathrm{Ct}$ values obtained with DNA from titrated suspensions were reported on the plots (Figure 3).

\section{TaqMan $^{\circ}$ Real-Time PCR assays for Psv, Psn and Psf specific detection}

$\mathrm{SYBR}^{\circ}$ Green Real-Time PCR is a reliable quantitative dye detection procedure, but unsuitable for multiple targets. In this perspective, on the sequences of the amplicons produced with the primer pairs $P s v \mathrm{RT}-\mathrm{F} / P s v \mathrm{RT}-\mathrm{R}$, PsnRT-F/PsnRT-R and PsfRT-F/PsfRT-R, the TaqMan probes PsvRT-P, PsnRT-P and PsfRT-P were designed to specifically identify $P s v, P s n$ and $P s f$ strains, respectively (Table 2). These fluorogenic probes were used in RealTime PCR runs with $1 \mu \mathrm{l}$ of DNA template, extracted from $1 \mathrm{ml}$ of various titrated suspensions (corresponding to $10^{3}, 10^{5}$ and $10^{7} \mathrm{CFU} /$ reaction) of strains Psv ITM317, Psn ITM519 and Psf NCPPB1464. As shown in Figure 4, all these TaqMan probes provided the desired level of specificity, and $\mathrm{Ct}$ values ranging from 12 to 27 were generated with target DNA extracted from $10^{3}$ to $10^{7} \mathrm{CFU}$. No significant changes in $\mathrm{Ct}$ were ever observed when target DNA was spiked with DNA from no-target $P$. savastanoi pathovars (50 ng/reaction each) or with DNA from the host plant of the target $P$. savastanoi pathovar and from a pool of bacterial epiphytes present on this plant (50 ng/reaction each). Fluorescence always remained below the threshold values in DNA-free controls. The specificity was further confirmed using as template DNA (50 ng) extracted from the bacteria listed in Table 1: an increase in fluorescence, at the expected wavelength, was always obtained for all the strains of a $P$. savastanoi pathovar when the reaction mixture contained the TaqMan probe supposed to be specific for that pathovar, as schematically reported in Table 1 . Negative results were always recorded using no-target DNAs.

The detection limits of TaqMan Real-Time PCR reactions were evaluated using different DNA amounts (from $50 \mathrm{ng}$ to $5 \mathrm{fg}$ per reaction) and standard curves for quantitative analyses were constructed for the three target $P$. 


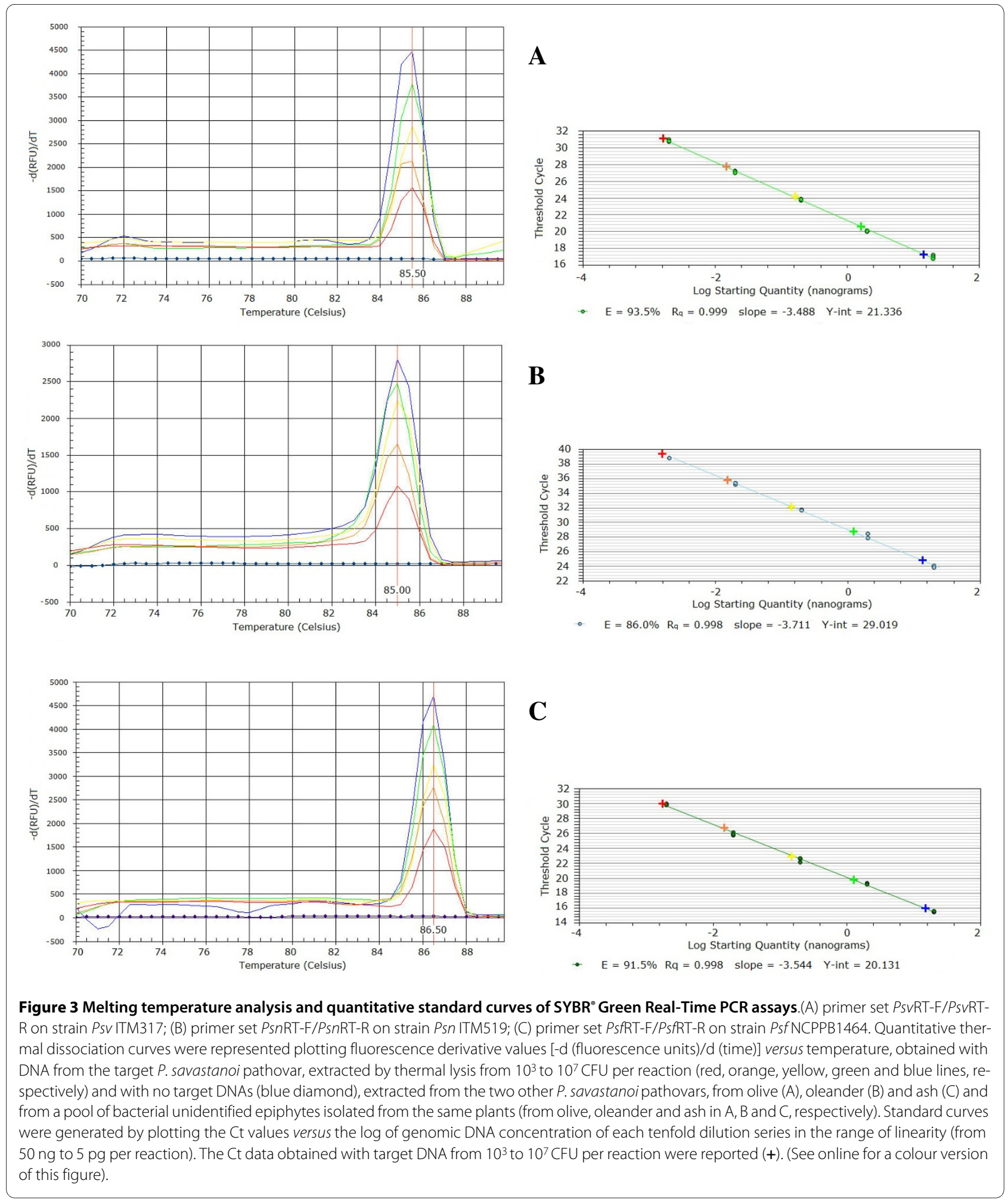

savastanoi pathovars, using $\mathrm{Ct}$ values from three independent runs of PCR assays with three replicates each, plotted versus the log of DNA concentration of each tenfold dilution series. Standard curves showed a linear correlation between input DNA and Ct values over a range of six logs (from $50 \mathrm{ng}$ to $0.5 \mathrm{pg}$ per reaction), for all the pathovar-specific P. savastanoi TaqMan probes (Figure 4). Detection limits were always $500 \mathrm{fg}$ of target DNA for Psv, Psn, and Psf, using the specific TaqMan probe, corresponding to about $10^{2}$ bacterial genomes. Concerning $\mathrm{R}^{2}$ 

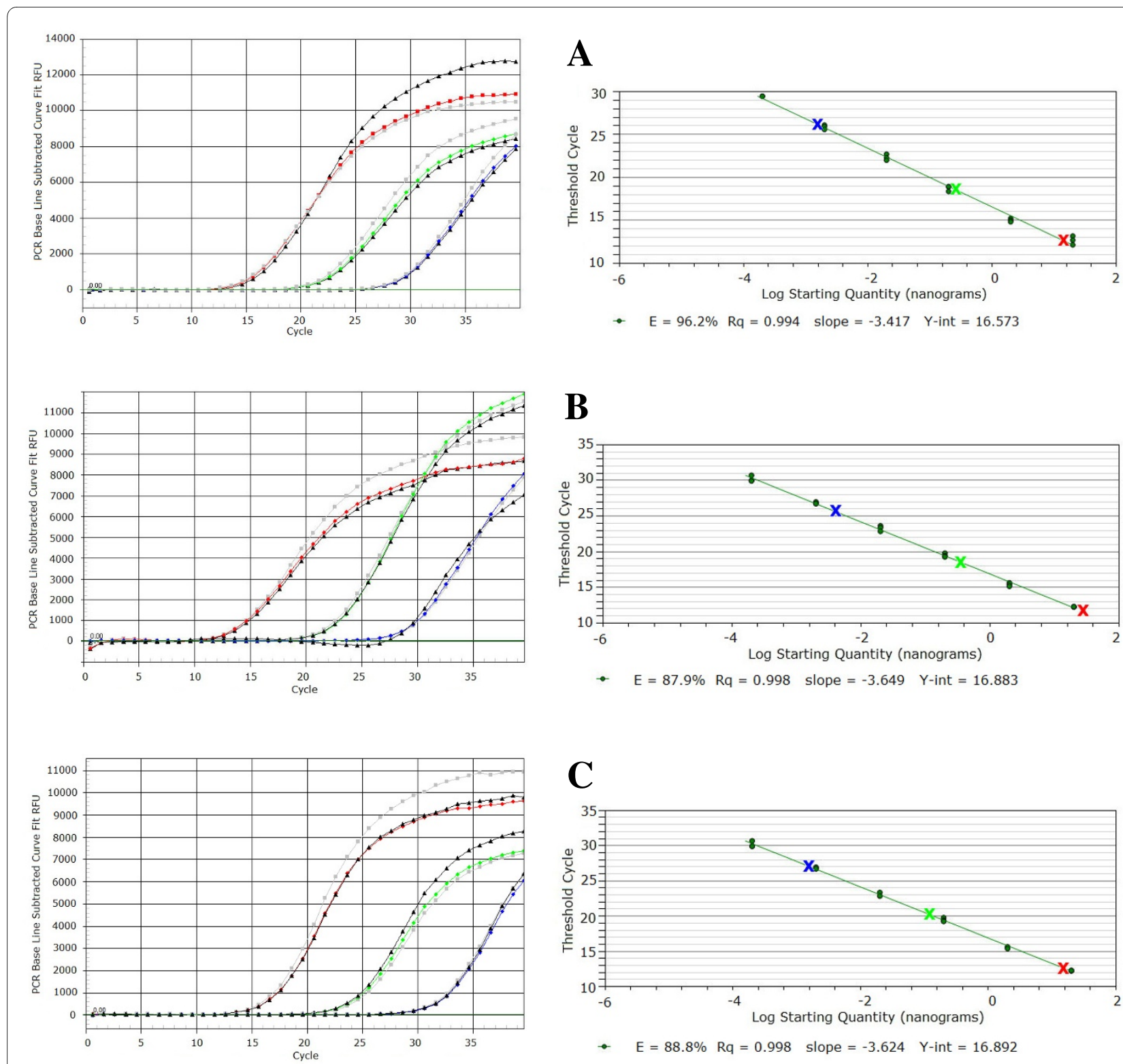

Figure 4 Sensitivity of TaqMan ${ }^{\circ}$ probes PsvRT-P (A), PsnRT-P (B) and PsfRT-P (C). Sensitivity was assessed by using DNA extracted from strains PsV ITM317 (A), Psn ITM519 (B) and Psf NCPPB1464 (C). Amplification curves of DNA from target P. savastanoi pathovar extracted from 103, $10^{5}$ and $10^{7}$ CFU per reaction and used pure (red diamond, green diamond and blue diamond, respectively) or spiked with no-target $P$. savastanoi pathovars DNA ( $50 \mathrm{ng} /$ reaction each) (black diamond) or with DNA from the host plant of target $P$. savastanoi pathovar and from a pool of bacterial epiphytes present on this plant ( $50 \mathrm{ng} /$ reaction each) (grey square). (See online for a colour version of this figure). Standard curves were generated by plotting the $\mathrm{Ct}$ values versus the log of genomic DNA concentration of each tenfold dilution series in the range of linearity (from $50 \mathrm{ng}$ to $0.5 \mathrm{pg}$ per reaction). The $\mathrm{Ct}$ data obtained with target DNA from $10^{3}$ to $10^{7} \mathrm{CFU}$ per reaction were reported (X). (See online for a colour version of this figure).

values, these were $0.994,0.998$ and 0.998 , with corresponding amplification efficiencies of $96.2 \%, 87.9 \%$ and 88.8\%, for the probes PsvRT-P, PsnRT-P and PsfRT-P, respectively (Figure 4).

\section{Multiplex Real-Time PCR assays for Psv, Psn and Psf specific detection on artificially inoculated olive plants}

In order to test whether the TaqMan probes here developed were compatible in multiplex reactions and whether they are applicable in vivo, some preliminary experiments were performed using as template DNA extracted by thermal lysis from olive leaves artificially inoculated with a bacterial suspension of strain Psv ITM317, alone or in combination with strains Psn ITM519 and Psf NCPPB1464, as described subsequently in Methods. The results obtained are reported in Figure 5, where all the three probes maintained the expected level of specificity in multiplex reactions as well, enabling the simultaneous 
detection of all the three target $P$. savastanoi pathovars, if present. The probe PsvRT-P gave always positive fluorescence signals at the expected wavelength, with almost the same $\mathrm{Ct}$ values in all the samples tested (Figure 5). The wavelength-specific fluorescence increase for the other two TaqMan probes, Psn-RT-P and Psf-RT-P, was observed only when the DNA template was extracted
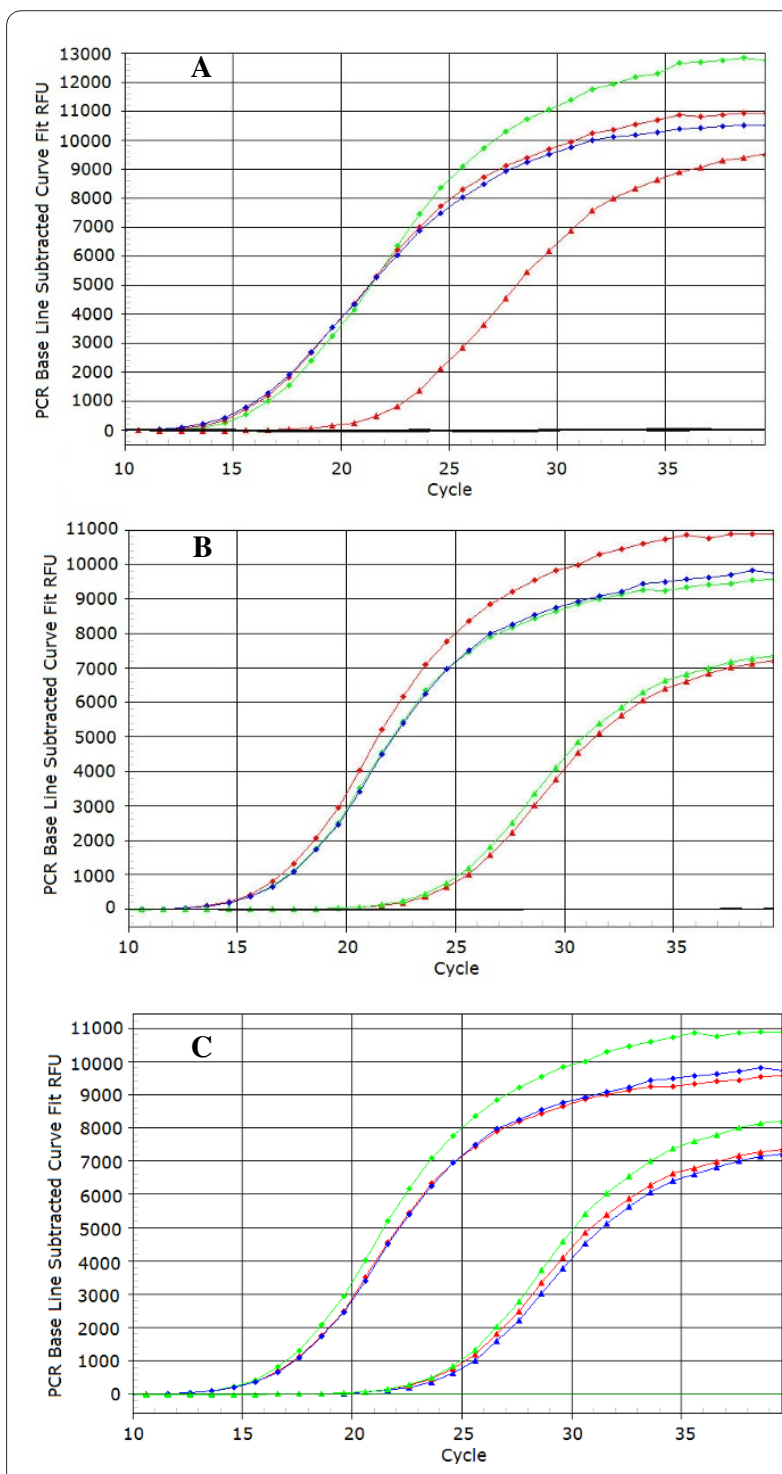

Figure 5 Sensitivity of TaqMan probes in Multiplex Real-Time PCR assays. Sensitivity of the TaqMan probes PSVRT-P, PsnRT-P and PsfRT-P was evaluated using $P$. savastanoi DNA extracted from olive leaves artificially inoculated with bacterial suspensions (107 CFU/leaf/ strain) of PSV ITM317 (red triangle), PSn ITM519 (green triangle) and PSf NCPPB1464 (blue triangle), according to the following scheme. (A) PSV ITM317; (B) Psv ITM317 + Psn ITM519; (C) PSV ITM317 + Psn ITM519 + Psf NCPPB1464. Amplification curves obtained with DNA from Psv ITM317 (red diamond), Psn ITM519 (green diamond) and Psf NCPPB1464 (blue diamond) (50 ng/reaction each) and from water and uninoculated leaves (-) were also shown for comparison. (See online for a colour version). from olive leaves also inoculated with the $P$. savastanoi pathovars for which these probes were previously demonstrated to be specific (Figure 5). No differences were observed among the Cts obtained with the probe PsvRT$\mathrm{P}$ and using as template the DNA extracted from the washings of leaves inoculated with strain Psv ITM317 alone or in combination with strains Psn ITM519 and Psf NCPPB1464 (Figure 5). For each probe, fluorescence always remained below the threshold values for the water controls, and for the DNA extracted from leaves inoculated with sterile water or uninoculated. Moreover the sensitivity of each TaqMan probe was unaffected by multiplexing, as assessed comparing the $\mathrm{Ct}$ values of the relative standard curves with those here obtained (Figure 4), both using pure DNA from Pss ITM317, Psn ITM519 and Psf NCPPB1464 (50 ng/reaction each), and DNA from the same pathovars extracted from olive leaves washings (corresponding to about $10^{5} \mathrm{CFU}$ per reaction for each $P$. savastanoi pathovar).

\section{Discussion}

PCR-based methods are being increasingly used for detecting phytopathogenic bacteria, as recently reviewed by Palacio-Bielsa et al. [50]. Traditional methods are mainly based on the isolation of bacterial plant pathogens on semi-selective media, followed by morphological identification. Such methods are time consuming, usually require deep taxonomic expertise and are not able to give accurate results for pathogen quantification. On the contrary PCR-based protocols allow rapid, precise and direct bacterial detection, even in planta. Moreover, some of these techniques give quantitative results and are able to simultaneously detect up to five different target pathogens. As far as P. savastanoi is concerned, sanitary certification programs for olive and oleander mother plants and propagation materials already started in many countries [41,51,52], but the presence of Psv and Psn on these plants is still assessed mainly by visual inspection, looking for the typical hyperplastic knots. On the other hand, it was clearly demonstrated that the spread of the disease can also occur with asymptomatic propagation materials, where these bacteria can be found either as endophytes or as epiphytes [37,38,53-55]. Hence innovative detection protocols for $P$. savastanoi pathovars, which have very low detection limits and are able to obtain good results in vivo, are strongly needed and can be achieved only by PCR-based methods. All the PCR-based protocols up to now available for $P$. savastanoi are unable to differentiate $P s v, P s n$ and Psf strains [44-47] and this could be an enormous limit for their routine applicability. In fact, while nothing is known yet about the natural distribution of Psv, Psn and Psf on the different hosts, cross-infections have been reported to occur under experimental conditions [21,24]. Thus, the availability of highly reliable 
pathovar-specific identification tests is both fundamental to definitely assess the natural host range of the P. savastanoi pathovars here examined and mandatory in light of the application of sanitary certification programs for olive and oleander.

In our study, a global approach was undertaken and for the first time a complex of PCR assays was developed for the highly specific and sensitive identification, detection and discrimination of the three pathovars Psv, Psn and $P s f$, in multiplex and quantitative reactions as well. These protocols were thought to be suitable both for research and for diagnostic purposes, with different laboratories applying End Point PCR or Real-Time PCR, using SYBR ${ }^{\circ}$ Green or pathovar-specific TaqMan probes, according to the aims of the work and to the available instrumentations and skills.

All these assays had a specificity score of $100 \%$, since the only positive strains are those belonging to the $P$. savastanoi pathovar for which the PCR-based protocol was designed. To this purpose forty-four P. savastanoi strains were tested, having different geographical origins and belonging to the pathovars Psv, Psn and Psf. Negative results were always obtained with closely taxonomically related bacteria, such as $P s p$ and $P s g$, and with bacterial epiphytes naturally occurring on leaves of olive, oleander and ash, as well as with DNA extracted from these plants and from oak, unless spiked with the $P$. savastanoi target DNA.

Concerning detection limits, positive results were obtained in End Point and Real-Time PCR with DNA amounts as small as 5 or 0.5 pg per reaction. Amounts of DNA corresponding to about $10^{2}-10^{3}$ genomes per reaction could be easily detected in Real-Time PCR runs, with Ct values ranging from 30 to 39 and from 26 to 27, with SYBR $^{\circ}$ Green or TaqMan probes, respectively, and according to the pathovar examined. The PCR protocols already available for the detection of Psv appeared to be slightly more sensitive than the assays developed in this study (from 10 to $10^{2} \mathrm{CFU} / \mathrm{ml}$ on enriched samples of amended plant extracts), but it is to point that no reliable comparison was possible among data obtained in conventional PCR and Real-Time PCR [44-46]. Concerning the quantitative assay previously developed for $P s n$, based on the real time monitoring of the reaction and on the use of a TaqMan probe [47], it had higher performances (10 $\mathrm{CFU} / \mathrm{ml}$ ) than those obtained with the same technical approach in the present study, but after a one-day enrichment step. Since the primers and the probes here designed are extremely pathovar-specific, the TaqMan ${ }^{\circ}$ Real-Time procedures developed were also demonstrated to be an excellent quantitative method even when applied to multiplex assays for Psv, Psn and Psf specific detection and discrimination on artificially inoculated olive plants.
As a precaution against the possibility of false negative results, due to the presence of PCR inhibitors in the samples or to malfunctions of the thermal cycler, it is necessary not only to choose a DNA extraction procedure which would be able to eliminate PCR inhibitors, but also to ascertain their absence through a systematic monitoring. To this aim an internal amplification control (IAC) is sometimes included in the assay to test both PCR performance and inhibition [56]. But in some cases IAC was demonstrated to alter the precision and accuracy of the PCR assay itself, particularly in Real-Time PCR experiments [57]. For this reason in this study the possibility of false-negative results on positive samples was completely excluded using a different and more efficient strategy. Prior to be used in the detection assays, DNAs extracted from bacteria were tested by amplifying $16 \mathrm{~S}$ rDNA with universal primers [58] and all the plant samples were tested as spiked with $50 \mathrm{ng} /$ reaction of target $P$. savastanoi bacterial DNA: only those giving positive results were then further processed, while those testing negative were rejected and their DNA extraction repeated.

\section{Conclusions}

The main novelty of this paper consists in the development of a versatile complex of PCR tools that for the first time will enable to easily and unequivocally distinguish Psv, Psn and Psf strains. The present End Point PCR assays are robust and suitable for routine culture confirmation purposes of these strains, avoiding laborious pathogenicity trials. Concerning the Real-Time PCR procedures, their high analytical sensitivity is definitely high enough for direct testing of plant materials, to detect the presence of these bacteria as epiphytes. Unlike the other assays published so far on in vivo PCR detection of Psv and Psn, the procedures here developed do not absolutely need any enrichment and nested-PCR, so that to avoid any possible contamination. Further experiments will focus on the upgrade of these protocols for the in planta detection of these bacteria as endophytes, encouraged by the results here obtained with the pathovar-specific TaqMan probes. Moreover because of their multiplexing activity, these probes are already available to yield new important insights into the epidemiology of Psv, Psn and Psf and of the diseases they caused.

\section{Methods}

\section{Bacterial strains and pathogenicity tests}

P. savastanoi strains used in this study are listed in Table 1. P. savastanoi strains were routinely grown on King's $B$ agar (KB) [59], incubated at $26^{\circ} \mathrm{C}$ for $48 \mathrm{~h}$. For liquid culture, bacteria were grown overnight on $\mathrm{KB}$ at $26^{\circ} \mathrm{C}$ on a rotary shaker $(160 \mathrm{rpm})$. Bacterial suspensions were prepared from liquid cultures: after centrifugation (10 $\mathrm{min}$ at $7,000 \mathrm{~g}$ ), the pellets were washed twice with sterile saline 
water (SSW, $0.85 \% \mathrm{NaCl}$ in distilled water) and then resuspended in an appropriate volume of SSW to give the desired concentration [expressed as Colony Forming Units (CFU) per ml]. The concentration of each suspension was verified by plating on KB agar plates $100 \mu \mathrm{l}$ of SSW serial dilutions and counting single colonies after 2 days of incubation at $26^{\circ} \mathrm{C}$.

Bacterial epiphytes naturally occurring on $P$. savastanoi host plants (olive, oleander and ash) were also isolated and included in this study. To this purpose two chemically untreated plants for each species were sampled, randomly removing three leaves per plant from one-year-old twigs. Each leaf was then resuspended in SSW $(50 \mathrm{ml}$ in a $100 \mathrm{cc}$ Erlenmeyer flask) and incubated at $26^{\circ} \mathrm{C}$ on a rotatory shaker $(200 \mathrm{rpm})$ for 18 hours. The leaves washings were then separately centrifuged $(8,000 \mathrm{~g}, 15 \mathrm{~min})$, each pellet resuspended in $200 \mu \mathrm{l}$ of SSW, and then used for plating on KB agar, containing cycloheximide $(50 \mu \mathrm{g} / \mathrm{ml})$ to avoid fungal growth. After an incubation of 2 days at $26^{\circ} \mathrm{C}, 50$ individual and different bacterial colonies from each leaf washing were randomly isolated and submitted as unidentified pool to DNA extraction.

For long term storage bacteria were maintained at $80^{\circ} \mathrm{C}$ on $20 \%(\mathrm{v} / \mathrm{v})$ glycerol.

In order to confirm their previous identification, almost-full-length 16S rRNA genes were amplified from all these isolates and amplifications were performed as described elsewhere [23]. The P. savastanoi strains used were also inoculated into 1-year-old olive, oleander and ash stems and tested for their pathogenicity and their virulence, as already described [21].

\section{DNA extraction from bacteria and plants}

Genomic DNA was extracted and purified from $1 \mathrm{ml}$ of bacterial titrated cultures (from $10^{6}$ to $10^{10} \mathrm{CFU} / \mathrm{ml}$ ), using Puregene ${ }^{\circ}$ DNA Isolation Kit (Gentra System Inc., MN, USA), according to manufacturers' instructions. DNA concentration was measured both spectrophotometrically, using a NanoDrop ${ }^{\mathrm{mm}}$ ND-1000 (NanoDrop Tecnologies Inc., DE, USA) and visually by standard agarose gel electrophoresis [1\% agarose (w:v) in TBE 1X] [60].

Bacterial DNA to be used immediately in PCR assays was also obtained by thermal lysis of the pellets from $1 \mathrm{ml}$ of the above mentioned titrated cultures. Each pellet was carefully resuspended in sterile distilled water $(100 \mu \mathrm{l} /$ pellet), incubated at $95^{\circ} \mathrm{C}$ for $10 \mathrm{~min}$ and immediately cooled on ice. After a quick spin in a microcentrifuge, $1 \mu \mathrm{l}$ lysate was directly used in PCR assays as template.

DNA from $P$. savastanoi host (olive, oleander and ash) and non-host (oak) plants was extracted using Puregene DNA Isolation Kit (Gentra System Inc.), according to procedure suggested by manufacturers for vegetable materials.
Prior to be used in PCR specific assays, DNA was always checked for its amplificability and the absence of PCR inhibitors, then testing only those giving positive results. Bacterial DNA was amplified using bacterial $16 \mathrm{~S}$ rDNA universal primers [58] and plant DNA preparations were tested after being spiked with 50 ng of the bacterial DNA target of the primer pair used.

\section{ERIC-PCR experiments and design of pathovar-specific primers}

The Rep-PCR experiments were carried out according to Louws et al. (1994) [61], with slight modifications and using Enterobacterial Repetitive Intergenic Consensus (ERIC) primers. The primers ERIC1R and ERIC2 [48] were synthesized by PRIMM (PRIMM srl, Milan, Italy). Amplifications were performed in a programmable thermal cycler Biometra $\mathrm{T}$ Professional Basic (Biometra, Goettingen, Germany), in thin-walled 0.5-ml Eppendorf tubes (Sarstedt, Numbrech, Germany), in a $25 \mu$ l volume with $50 \mathrm{ng}$ of DNA template per reaction. The reaction mixture and the cycling protocol were already described [62]. Negative controls were included in all PCR amplifications to test for contaminants in the reagents used. For each bacterial isolate, amplification reactions were conducted at least twice, in three separate experiments. Aliquots $(10 \mu \mathrm{l})$ of PCR products were analysed by electrophoresis in $2 \%(\mathrm{w}: \mathrm{v})$ agarose gels with $1 \times \mathrm{TAE}$ buffer [60], stained with ethidium bromide. The results were visualized, recorded by a video camera and processed by Alphaimager ${ }^{\text {Tw }}$ system (Alpha Innotech Corporation, San Leandro, CA, USA). The length of the DNA fragments was estimated by comparison with $1 \mathrm{~Kb}$ Plus DNA Ladder (Invitrogen Inc, Carlsbad, CA, USA). Amplification profiles were analysed by visual examinations and those amplicons supposed to be pathovar-specific were purified from agarose gel with PureLink Quick Gel Extraction Kit (Invitrogen) and cloned using TOPO TA Cloning Kit (Invitrogen) and chemically competent $E$. coli DH5-a cells, under the conditions recommended by the manufacturer. Recombinant plasmids were purified with NucleoSpin Plasmid kit (Macherey-Nagel GmbH, Duren, Germany) and used as template with universal primer T7 and SP6 to generate probes individually labelled with a nonradioactive digoxigenin (DIG) kit (Roche Diagnostics, Mannheim, Germany), according to the manufacturer's instructions. Dot blot analyses were then performed on genomic DNA from Psv, Psn and Psf representative strains blotted on nylon membranes [60]. ERIC-clones generating pathovar-specific probes were then double-strand sequenced at Eurofins MWG Operon Ltd (Ebersberg, Germany). Multiple sequence alignments and comparisons were performed using the computer package CLUSTALW (version 2) [63] www.ebi.ac.uk/Tools/clustalw2 and by means of Basic 
Local Alignment Search Tool (BLAST) http:// www.ncbi.nlm.nih.gov/blast analyses to explore all the available DNA sequences in international databases. According to this analysis and using Beacon Designer 7.5 software (Premier Biosoft International, Palo Alto, CA, USA) pathovar-specific primer pairs and probes were designed and synthesized (PRIMM srl), to be used in End Point and Real-Time PCR assays, with SYBR Green I detection dye and $\mathrm{TaqMan}^{\circ}$ hybridisation probes (Table 2).

\section{End Point and Real-Time PCR: assay conditions}

End Point PCR amplifications were carried out in a $25 \mu \mathrm{l}$ reaction mixture which contained DNA template (in variable amounts according to the specific experimental purposes), $67 \mathrm{mM}$ TrisHCl, $\mathrm{pH} 8.8,16 \mathrm{mM}\left(\mathrm{NH}_{4}\right)_{2} \mathrm{SO}_{4}$, $0.01 \%$ Tween $20,1.5 \mathrm{mM} \mathrm{MgCl}_{2}, 200 \mu \mathrm{m}$ of each dNTP, $0.5 \mu \mathrm{M}$ of each primer, 1 unit Taq DNA polymerase (EuroTaq, Euroclone SpA, Milan, Italy). Amplification was performed in a thermal cycler (Biometra T Professional Basic, Biometra, Goettingen, Germany), using a cycle profile of $95^{\circ} \mathrm{C}(30 \mathrm{sec}), 60^{\circ} \mathrm{C}(30 \mathrm{sec})$ and $72^{\circ} \mathrm{C}(1$ min) for 40 cycles, plus an initial step of $95^{\circ} \mathrm{C}$ for $3 \mathrm{~min}$ and a final step of $72^{\circ} \mathrm{C}$ for $10 \mathrm{~min}$. PCR reaction products $(5 \mu \mathrm{l})$ were detected by $1.5 \%$ agarose gel electrophoresis in TAE 1X stained with ethidium bromide $(0.5 \mu \mathrm{g} / \mathrm{ml})$ and sequenced for confirmation at Eurofins MWG Operon Ltd (Ebersberg, Germany).

Real-Time PCR experiments were performed using the iQ5 Cycler - Real-Time PCR Detection System (Bio-Rad, Hercules, CA, USA), in PCR plates (96 well), with $25 \mu \mathrm{l}$ reaction mixture volume, the primers and the probes reported in Table 2, and variable DNA amounts depending on the experimental purposes. Each sample, including standards and those DNA-free used as negative control, were run in triplicate and assayed in three independent experiments.

SYBR ${ }^{\circ}$ Green Real-time PCR was performed using iQ SYBR $^{\circ}$ Green Supermix (Bio-Rad) according to the manufacturer's instructions. TaqMan Real-time PCR was performed using $\mathrm{iQ}^{\circ}$ Multiplex Powermix (Bio-Rad), under the conditions recommended by the manufacturer.

\section{End Point and Real-Time PCR: specificity and detection limits}

The specificity of the PCR assays here developed was tested on genomic DNA from P. savastanoi strains listed in Table 1, on genomic DNA from olive, oleander, ash and oak, and on total DNA from pools of unidentified bacterial epiphytes isolated from $P$. savastanoi host plants as already described.

The detection limits of these PCR procedures were evaluated by using as template total genomic DNA of representative strains (Psv ITM317, Psn ITM519 and Psf
NCPPB1464), serially tenfold diluted (from $50 \mathrm{ng}$ to 0.05 pg or to $5 \mathrm{fg}$ per reaction) or extracted by thermal lysis from $1 \mathrm{ml}$ titrated bacterial cultures (from $10^{6}$ to $10^{10}$ $\mathrm{CFU} / \mathrm{ml}$, with $1 \mu \mathrm{l}$ DNA per reaction), according to the experimental purposes.

In Real-Time PCR the threshold cycle $(\mathrm{Ct})$ value of each sample depends on the initial amount of the target sequence in the reaction so that it is inversely proportional to the decimal logarithm (log) of the copy number. According to the $\mathrm{Ct}$ values obtained, for each $P$. savastanoi pathovar a standard curve was constructed to calculate the correlation between the amount of bacterial DNA and the Ct value, in order to quantify $P$. savastanoi DNA present in unknown samples by interpolation with the linear regression curve.

\section{Multiplex Real-Time PCR on artificially inoculated plants}

Mature leaves were randomly removed from one-yearold twigs of two chemically untreated olive plants, washed in running tap water for $30 \mathrm{~min}$ and rinsed three times in an appropriate volume of SSW. After being air dried on a paper towel and in a laminar air flow cabinet, the leaves were aseptically transferred in Petri dishes $(90$ $\mathrm{mm}$ diameter) containing a sterile filter paper disk (3 leaves/plate). Leaves were then separately inoculated with bacterial suspensions of strain Psv ITM317 alone or mixed with strains Psn ITM519 and Psf NCPPB1464, and incubated for 24 hours at $26^{\circ} \mathrm{C}$.

Each leaf was inoculated with $100 \mu \mathrm{l}$ of bacterial suspension with about $10^{8} \mathrm{CFU} / \mathrm{ml} /$ strain. Negative controls were provided by leaves inoculated with sterile water or uninoculated. Three replicates for each inoculation treatment and three independent trials were performed. Each leaf was resuspended in $10 \mathrm{ml}$ of SSW, incubated at $26^{\circ} \mathrm{C}$ on a rotatory shaker $(200 \mathrm{rpm})$ for 1 hour. The leaves washings were then separately centrifuged $(8,000 \mathrm{~g}, 15$ $\mathrm{min})$, each pellet resuspended in $100 \mu \mathrm{l}$ sterile distilled water and subjected to DNA thermal extraction. One $\mu \mathrm{l}$ of lysate was directly used as template in Multiplex RealTime PCR experiments, using the three TaqMan probes developed in this study and according to the protocol described above. As positive controls, genomic DNAs of strains Psv ITM317, Psn ITM519 and Psf NCPPB1464 were used (50 ng/reaction).

\section{Authors' contributions}

ST coordinated the study, participated in the concept development and in the assays design, the analysis and interpretation of the results, and drafted the manuscript. MC participated in the concept development and in the assays design, carried out sample preparation and optimization of PCR experimental procedures, the analysis and interpretation of the results, and helped with the manuscript preparation. IML carried out sample preparation and PCR experimental procedures, and helped with analysis and interpretation of the results. ES was involved in the initial study design, participated in sample selection and performed some of the preliminary experiments. All authors read and approved the final manuscript. 


\section{Acknowledgements}

This study was supported by Ente Cassa di Risparmio di Firenze (Ref. 2007.1005; 2008.1573). We are grateful to A. Sisto, V. Catara, M. L. Lopez, E. J. Cother, R. W. Jackson and M. S. Ullrich for providing some of the isolates used in this study. Thanks are due to M. Picca Nicolino and A. Gori for their technical assistance, to F. Sebastiani for critically reviewing the manuscript and to M. Bencini for English revision.

\section{Author Details}

Dipartimento di Biotecnologie Agrarie, Sez. Patologia vegetale, Laboratorio di Patologia Vegetale Molecolare, Università degli Studi di Firenze, Via della Lastruccia 10, 50019 Sesto Fiorentino, Firenze, Italy

Received: 28 December 2009 Accepted: 28 May 2010

Published: 28 May 2010

\section{References}

1. Schroth MN, Hilderbrand DC, O'Reilly HJ: Off-flavor of olives from trees with olive knot tumors. Phytopathol 1968, 58:524-525.

2. Schroth MN, Osgood JW, Miller TD: Quantitative assessment of the effect of the olive knot disease on olive yield and quality. Phytopathol 1973, 63:1064-1065

3. Gardan L, Bollet C, Abu Ghorrah M, Grimont F, Grimont PAD: DNA relatedness among the pathovar strains of Pseudomonas syringae subsp. savastanoi Janse (1982) and proposal of Pseudomonas savastanoi sp. nov. Int J Syst Bacteriol 1992, 42:606-612.

4. Young JM, Saddler GS, Takikawa Y, De Boer SH, Vauterin L, Gardan L, Grozdyak RI, Stead DE: Names of plant pathogenic bacteria 1864-1995. Rev Plant Pathol 1996, 75:721-763.

5. Savastano L: Tubercolosi, iperplasie e tumori dell'olivo. Memoria Ann Scuola Sup Agric Portici 1887, 5:1-117.

6. Savastano L: Il bacillo della tubercolosi dell'olivo. Rend Regia Accad Lincei 1889, 5:92-94.

7. Ciccarone A: Alterazioni da freddo e da rogna sugli ulivi, esemplificate dai danni osservati in alcune zone pugliesi negli anni 1949-1950. Boll Staz Patol Veg Roma 1950, 6:141-174.

8. Sisto A, Cipriani MG, Morea M: Knot formation caused by Pseudomonas syringae subsp. savastanoi on olive plants is hrp-dependent. Phytopathol 2004, 94:484-489.

9. Comai L, Kosuge T: Involvement of plasmid deoxyribonucleic acid in indoleacetic acid synthesis in Pseudomonas savastanoi. J Bacteriol 1980, 143:950-957.

10. Comai L, Kosuge T: Cloning and characterization of iaaM, a virulence determinant of Pseudomonas savastanoi. J Bacteriol 1982, 149:40-46.

11. Smidt M, Kosuge $T$ : The role of indole-3-acetic acid accumulation by alpha-methyl tryptophan-resistant mutants of Pseudomonas savastanoi in gall formation in oleander. Physiol Plant Pathol 1978, 13:203-214

12. Surico G, lacobellis NS, Sisto A: Studies on the role of indole-3-acetic acid and cytokinins in the formation of knots on olive and oleander plants by Pseudomonas syringae pv. savastanoi. Physiol Plant Pathol 1985, 26:309-320

13. Rodríguez-Moreno L, Barceló-Muñoz A, Ramos C: In vitro analysis of the interaction of Pseudomonas savastanoi pvs. savastanoi and nerii with micropropagated olive plants. Phytopathol 2008, 98:815-822.

14. Casano FJ, Hung JY, Wells JM: Differentiation of some pathovars of Pseudomonas syringae with monoclonal antibodies. EPPO Bulletin 1987, 17:173-176

15. Janse JD: Pseudomonas syringae subsp. savastanoi (ex Smith) subsp. nov., nom. rev., the bacterium causing excrescences on Oleaceae and Nerium oleander L. Int J Syst Bacteriol 1982, 32:166-169.

16. Janse JD: Pathovar discrimination within Pseudomonas syringae subsp. savastanoi using whole-cell fatty acids and pathogenicity as criteria. Syst Appl Microbiol 1991, 13:79-84.

17. Mugnai L, Giovannetti L, Ventura S, Surico G: The grouping of strains of Pseudomonas syringae subsp. savastanoi by DNA restriction fingerprinting. J Phytopathol 1994, 142:209-218.

18. Caponero A, Contesini AM, lacobellis NS: Population diversity of Pseudomonas syringae subsp. savastanoi on olive and oleander. Plant Pathol 1995, 44:848-855.
19. Alvarez F, Garcia de los Rios JE, Jimenez P, Rojas A, Riche P, Troya MT: Phenotypic variability in different strains of Pseudomonas syringae subsp. savastanoi isolated from different hosts. Eur J Plant Pathol 1998, 104:603-609.

20. lacobellis NS, Contesini AM, Surico G: Bacteriocin production by Pseudomonas syringae subsp. savastanoi. Phytopathol Mediterr 1995, 34:15-22.

21. lacobellis NS, Caponero A, Evidente A: Characterization of Pseudomonas syringae ssp. savastanoi strains isolated from ash. Plant Pathol 1998, 47:73-83.

22. Sisto A, Morea M, Baruzzi F, Palumbo G: Differentiation of Pseudomonas syringae subsp. savastanoi strains isolated from various host plants by restriction fragment length polymorphism. Phytopathol Mediterr 2002 41:63-71.

23. Sisto A, Cipriani MG, Tegli S, Cerboneschi M, Stea G, Santilli E: Genetic characterization by fluorescent AFLP of Pseudomonas savastanoi pv. savastanoi strains isolated from different host species. Plant Pathol 2007, 56:366-372.

24. Surico G, lacobellis NS: Phytohormone and olive knot disease. In Molecular Signals in Plant-Microbe Communications Edited by: Verma DPS CRC Press, Boca Raton, FL, USA; 1992:209-229.

25. Scortichini M, Rossi MP, Salerno M: Relationship of genetic structure of Pseudomonas savastanoi pv. savastanoi populations from Italian olive trees and patterns of host genetic diversity. Plant Pathol 2004, 53:491-497

26. Quesada JM, Pérez-Martinez I, Ramos C, López MM, Penyalver R: IS53: an insertion element for molecular typing of Pseudomonas savastanoi pv. savastanoi. Res Microbiol 2008, 159:207-215.

27. Matas IM, Pérez-Martínez I, Quesada JM, Rodríguez-Herva JJ, Penyalver R, Ramos C: Pseudomonas savastanoi pv. savastanoi contains two iaal paralogs, one of which exhibits a variable number of a trinucleotide (TAC) tandem repeat. Appl Environ Microbiol 2009, 75:1030-1035.

28. Krid S, Rhouma A, Quesada JM, Penyalver R, Gargouri A: Delineation of Pseudomonas savastanoi pv. savastanoi strains isolated in Tunisia by random-amplified polymorphic DNA analysis. J App/ Bacterio/ 2009, 106:886-894.

29. Varvaro L, Surico G: Comportamento di diverse cultivars di Olivo (Olea europaea L.) alla inoculazione artificiale con Pseudomonas savastanoi (E. F. Smith) Stevens. Phytopathol Mediterr 1978, 17:174-178.

30. Hassani D, Buonaurio R, Tombesi A: Response of some olive cultivars, hybrid and open pollinated seedling to Pseudomonas savastanoi pv. savastanoi. In Pseudomonas syringae and Related Pathogens Edited by: lacobellis NS, Collmer A, Hutcheson SW, Mansfield JW, Morris CE, Murillo J, Schaad NW, Stead DE, Surico G, Ullrich MS. Kluwer Academic Publishers, the Netherlands; 2003:489-494.

31. Young JM, Paula Wilkie J, Fletcher MJ, Park DC, Pennycook SR, Triggs CM, Watson DRW: Relative tolerance of nine olive cultivars to Pseudomonas savastanoi causing bacterial knot disease. Phytopathol Mediterr 2004, 43:395-402.

32. Penyalver R, García A, Ferrer A, Bertolini E, Quesada JM, Salcedo Cl, Piquer J, Pérez-Panadés J, Carbonell EA, del Río C, Caballero JM, López MM: Factors affecting Pseudomonas savastanoi pv. savastanoi plant inoculations and their use for evaluation of olive cultivar susceptibility. Phytopathol 2006, 96:313-319.

33. Ercolani GL: Presenza epifitica di Pseudomonas savastanoi (E. F. Smith) Stevens sull'Olivo, in Puglia. Phytopathol Mediterr 1971, 10:130-132.

34. Ercolani GL: Pseudomonas savastanoi and other bacteria colonizing the surface of olive leaves in the field. J Gen Microbiol 1978, 109:245-57.

35. Ercolani GL: Variability among Isolates of Pseudomonas syringae pv. savastanoi from the Philloplane of the Olive. J Gen Microbiol 1983, 129:901-916.

36. Lavermicocca P, Surico G: Presenza epifitica di Pseudomonas syringae pv. savastanoi e di altri batteri sull'Olivo e sull'Oleandro. Phytopathol Mediterr 1987, 26:136-141.

37. Quesada JM, García A, Bertolini E, López MM, Penyalver R: Recovery of Pseudomonas savastanoi pv. savastanoi from symptomless shoots of naturally infected olive trees. Int Microbio/ 2007, 10:77-84.

38. Quesada JM, Penyalver R, Pérez-Panadés J, Salcedo CI, Carbonell EA, López MM: Dissemination of Pseudomonas savastanoi pv. savastanoi populations and subsequent appearance of olive knot disease. Plant Pathol 2010, 59:262-269. 
39. Cazorla FM, Arrebola E, Sesma A, Perez-Garcia A, Codina Jc, Murillo J, De Vicente A: Copper resistance in Pseudomonas syringae strains isolated from mango is encoded mainly by plasmids. Phytopathol 2002, 92:909-916.

40. Renick LJ, Cogal AG, Sundin GW: Phenotypic and genetic analysis of epiphytic Pseudomonas syringae populations from sweet cherry in Michigan. Plant Dis 2008, 92:372-378.

41. EPPO: Pathogen-tested olive trees and rootstocks. EPPO Bull 2006, 36:77-83

42. Surico G, Lavermicocca P: A semiselective medium for the isolation of Pseudomonas syringae pv. savastanoi. Phytopathol 1989, 79:185-190.

43. Young JM, Triggs CM: Evaluation of determinative tests for pathovars of Pseudomonas syringae van Hall 1902. J App/ Bacteriol 1994, 77:195-207.

44. Penyalver R, Garcìa A, Ferrer A, Bertolini E, López MM: Detection of Pseudomonas savastanoi pv. savastanoi in olive plants by enrichment and PCR. Appl Environ Microbiol 2000, 66:2673-2677.

45. Bertolini E, Olmos A, López MM, Cambra M: Multiplex nested reverse transcription-polymerase chain reaction in a single tube for sensitive and simultaneous detection of four RNA viruses and Pseudomonas savastanoi pv. savastanoi in olive trees. Phytopathol 2003, 93:286-292.

46. Bertolini E, Penyalver R, Garcia A, Olmos A, Quesada JM, Cambra M, López MM: Highly sensitive detection of Pseudomonas savastanoi pv. savastanoi in asymptomatic olive plants by nested-PCR in a single closed tube. J Microbiol Methods 2003, 52:261-266.

47. Bella P, Licciardello G, Tessitori M, Catara V: A real-time PCR quantitative detection assay for Pseudomonas savastanoi pv. nerii in Nerium oleander. Phytopathol Mediterr 2008, 47:204-213.

48. Versalovic J, Schneider M, De Bruijn FJ, Lupski JR: Genomic fingerprinting of bacteria using repetitive sequence based polymerase chain reaction. Methods Mol Cell Biol 1994, 5:25-40.

49. Atmakuri K, Cascales E, Christie PJ: Energetic components VirD4, VirB11 and VirB4 mediate early DNA transfer reactions required for bacterial type IV secretion. Mol Microbiol 2004, 54:1199-1211.

50. Palacio-Bielsa A, Cambra MA, López MM: PCR detection and identification of plant-pathogenic bacteria: updated review of protocols (1989-2007). J Plant Pathol 2009, 91:249-297.

51. Sheppard A, Julien M: La Politique Sanitaire De L'australie Face Aux Menaces Des Maladies Végétales émergentes. Australian Biosecurity Policies and Applications for Emerging Plant Pathogens 2006.

52. Department of Agriculture and Cooperation, Ministry of Agriculture, Government of India: Plant Quarantine Regulation of Import into India. S.O.No.1322(E) 2003 [http://agricoop.nic.in/Gazette/PQ9310.pdf].

53. Wilson EE, Magie AR: Systemic invasion of the host plant by the tumorinducing bacterium, Pseudomonas savastanoi. Phytopathol 1964, 54:576-579.

54. Azad HR, Cooksey DA: A selective medium for detecting epiphytic and systemic populations of Pseudomonas savastanoi from oleander. Phytopathol 1995, 85:740-745.

55. Marchi G, Mori B, Pollacci P, Mencuccini M, Surico G: Systemic spread of Pseudomonas savastanoi pv. savastanoi in olive explants. Plant Pathol 2009, 58:152-158.

56. Hoorfar J, Cook N, Malorny B, Wagner M, De Medici D, Abdulmawjood A, Fach P: Diagnostic PCR: making internal amplification control mandatory. J App/ Microbiol 2004, 96:221-222.

57. Selma MV, Martinez-Culebras PV, Aznar R: Real-time PCR based procedures for detection and quantification of Aspergillus carbonarius in wine grapes. Int J Food Microbiol 2008, 122:126-134.

58. Caccamo D, Di Cello FP, Fani R, Gugliandolo C, Maugeri TL: Polyphasic approach to the characterisation of marine luminous bacteria. Res Microbiol 1999, 150:221-230

59. King EO, Ward MK, Raney DE: Two simple media for the demonstration of pyocyanin and fluorescein. J Lab Clin Med 1954, 44:301-307.

60. Sambrook J, Russell DW: Molecular Cloning: A Laboratory Manual. 3rd edition. Cold Spring Harbor Laboratory, Cold Spring Harbor Press, NY; 2001.

61. Louws FJ, Fulbright DW, Stephens CT, de Bruijn FJ: Specific genomic fingerprints of phytopathogenic Xanthomonas and Pseudomonas pathovars and strains generated with repetitive sequences and PCR. Appl Environ Microbiol 1994, 60:2286-2295.

62. Tegli S, Sereni A, Surico G: PCR-based assay for the detection of Curtobacterium flaccumfaciens pv. flaccumfaciens in bean seeds. Lett App/ Microbiol 2002, 35:331-337.
63. Thompson JD, Higgins DG, Gibson TJ: CLUSTAL W: improving the sensitivity of progressive multiple sequence alignment through sequence weighting, position-specific gap penalties and weight matrix choice. Nucleic Acids Res 1994, 22:4673-4680.

doi: $10.1186 / 1471-2180-10-156$

Cite this article as: Tegli et al., Development of a versatile tool for the simultaneous differential detection of Pseudomonas savastanoi pathovars by End Point and Real-Time PCR BMC Microbiology 2010, 10:156

\section{Submit your next manuscript to BioMed Central} and take full advantage of:

- Convenient online submission

- Thorough peer review

- No space constraints or color figure charges

- Immediate publication on acceptance

- Inclusion in PubMed, CAS, Scopus and Google Scholar

- Research which is freely available for redistribution 